\title{
Temporary Crops in the Brazilian Agricultural Frontier
}

\author{
Rogério Edivaldo Freitas (1) \\ Department of Regional Studies, Institute of Applied Economic Research, Brasília, Brazil \\ Email: rogerio.freitas@ipea.gov.br
}

How to cite this paper: Freitas, R.E. (2022) Temporary Crops in the Brazilian Agricultural Frontier. Agricultural Sciences, 13, 244-267.

https://doi.org/10.4236/as.2022.132017

Received: January 12, 2022

Accepted: February 22, 2022

Published: February 25, 2022

Copyright (c) 2022 by author(s) and Scientific Research Publishing Inc. This work is licensed under the Creative Commons Attribution International License (CC BY 4.0).

http://creativecommons.org/licenses/by/4.0/

\begin{abstract}
Food production remains one of the main challenges for humankind in this century, and Brazil is one of the largest food-producing countries that have yet some land for economically or technically profitable farming expansion. Moreover, knowing which areas constitute the Brazilian agricultural frontier is crucial for improving public policies and logistics infrastructure decisions. Data from the Brazilian Institute of Geography and Statistics from 1995 to 2019 were used in this study. We aimed to map and measure the expansion of agricultural areas in Brazil from 1995 to 2019 for temporary crops according to their mesoregions. We used a four-stage methodology, compared the results of two agglomerative clustering methods, and identified similar mesoregions based on their share trends in the Brazilian agricultural seeded area. Some mesoregions had higher positive trend values for their share of the Brazilian agricultural seeded area: Mato-grossense North (MT), Mato-grossense Northeast (MT), Mato Grosso do Sul Southwest (MS), Goiano South (GO), Extreme West Bahia (BA), Maranhense South (MA), Piauiense Southwest (PI), and Tocantins Eastern (TO). As a second leading group, the Paranaíba Upstream (MG), São José do Rio Preto (SP), Mato-grossense Southeast (MT), and Goiano East (GO), must be emphasized. Further research is recommended, including extending the study to permanent crops and applying top-down analysis targeting microregions or municipalities in the identified mesoregions.
\end{abstract}

\section{Keywords}

Agricultural Frontier, Brazil, Mesoregions, Spearman's Correlation Coefficient, Clustering

\section{Introduction}

Food production remains a central concern for humanity. The world population 
will reach 9.7 billion in 2050 [1] and urbanization is a current process in larger developing countries in Africa, China, and India. Meanwhile, most of the leading food-producing countries (Russia, the United States, Argentina, Canada, the European Union, and Australia) do not have more land for economically or technically profitable farming.

Further, much of the land already employed worldwide has several constraints, such as chemical contamination, physical degradation of soil, endemic diseases, or lack of infrastructure [2]. Some of this land is also forested, protected, or supports traditional settlements, and agricultural systems in Africa and Southeast Asia appear to be vulnerable to changes in agricultural water demand against the backdrop of an evolving climate [3].

In Brazil, agriculture has expanded from the South towards the Center-West region since the 1980s and has reached the states of Maranhão, Tocantins, Piauí, and Bahia (MATOPIBA) in the Northeast region and southern portions of the North region. Gasques et al. [4], for example, highlighted increasing land prices as a consequence of agricultural expansion in Pará, Amazonas, and the Tocantins states. Accordingly, specific agricultural expansion areas include the Tocantins East, Maranhão South, Piauí Southwest, and Extreme West Bahia. These areas may be responsible for the future expansion of crops in Brazil from 2020 to 2050 [5] [6].

Since Brazil is one of the most important food producers and exporters worldwide, it is critical to map and monitor its agricultural area expansion. Firstly, knowing the locus of the Brazilian agriculture area expansion is crucial for adjusting and supporting the respective public policies related to infrastructure, credit supply, technical assistance, and education for farmers. Secondly, private sectors linked to agricultural inputs can also employ such information to model their local operation strategies and investments decisions.

Thus, this study aims to map and measure the expansion of agricultural areas for temporary crops in Brazil from 1995 to 2019 by mesoregions. The following sections of this paper are organized as follows. Section 2 discusses agricultural area expansion in Brazil and abroad. The third section presents the methodology and database employed; Section 4 reports and discusses the results, and the final section concludes the paper with the closing remarks.

\section{Agricultural Area Expansion in Brazil and Abroad}

As highlighted by Awokuse and Xie [7], the remarkable expansion of the agricultural sector in Brazil has contributed to the growth of the overall economy, becoming a top producer and exporter of beef, broiler chickens, coffee, soybeans, oilseeds, sugar, and ethanol extracted from sugarcane. However, the expansion of the agricultural area of Brazil is associated with several problems.

A degraded pasture is a major liability in Brazilian agriculture, but restoration and recovery efforts could turn this area into a new frontier for both agricultural yield expansion and forest restoration [8]. Conversely, Guilherme and Vidica [9] 
argued that sustainable rural development, integration, and interaction of livestock, agricultural, and forestry components can contribute to reducing the impacts of the productive sector in the environment.

At the same time, finding a balance between ecosystem conservation and the production of goods and services that societies need to prosper is fundamental to the long-term sustainable development of any region, but this balance varies within the region's landscapes [10].

For example, specific techniques can be very useful for intercropping. According to [11], positive yield and natural resource effects of intercropping can still be realized if the ongoing farm-scale enlargement policy is combined with a policy promoting novel intercropping types, particularly those types that can make use of already available machinery.

Another important aspect is the effect of agricultural area expansion on soil coverage. Land use and land cover changes affect climate through both biogeochemical (BGC) and biophysical (BPH) mechanisms [12]. While BGC effects are assessed on a global scale and are at the heart of climate treaties such as the Paris Agreement, BPH effects are absent despite their increasingly recognized impact, especially at the local scale.

In international experience, specific countries are the focus of several approaches for combining public policies, agri-environmental concerns, and agricultural area expansion. For the European Union, Braito et al. [13] advocated appealing to human-nature relationships, offering training and experimentation services, fostering social networks, and raising the social reputation of farmers. Another great agricultural producer, the United States, also has singularities in agricultural area growth. Accordingly, agricultural policy exerts substantial influence on cropland areas in the United States through the administration of the Conservation Reserve Program (CRP) [14]. At the same time, in the Vietnam case, increases in crop production and land investment associated with holding land titles are driven by the intensive margin and some evidence that increasing the intensive margin of tenure (holding constant the extensive tenure) decreases deforestation [15].

Different types of farming also have different effects on the expansion of agricultural areas, and information and continuous education have become key for all kinds of farmers under the concept of smart farming. It refers to the use of information and communication technology in farm management, focusing simultaneously on productivity, profitability, and the conservation of natural resources [16]. Adoption of some technologies requires more years of education and knowledge about how technology works, and some technologies demand a greater scale.

In the last decade for example, Brazilian family farming has experienced significant changes in the national scenario altering the productive and social dynamics of family agriculture (FA), and public policies, such as technical assistance and rural extension (TARE), which can play an important role in its 
strengthening [17]. This study concluded that the structuring of a new and efficient national TARE system must rely on 1) state action, but not with the claim that they are the only source of such services; 2) expansion of the performance of municipalities, where the participation of city halls may contribute to TARE becoming a quality service; 3) continuous and quality training for extension workers; 4) creation of innovative financing mechanisms; and 5) promoting the integration of research and extension.

In larger areas, such as the Amazon, small farmers occupy a large swath and often lack access to technical assistance, production technology, and markets. Providing quality technical assistance to small farmers could help them better align production practices with local opportunities, increase household income and improve livelihoods, reducing deforestation pressure [18].

Azevedo-Ramos et al. [19] in their study, evaluated the northern region of Brazil. The Brazilian Amazon has 49.8 million hectares (Mha) of public forestlands not allocated by the federal or state governments to a specific tenure status: the so-called undesignated public forests (UPF). Historically, these public forests have been vulnerable to land grabbers and land speculation. More importantly, the seriousness and precariousness of the protection of Brazilian Amazon UPF, the rapid conversion of forests outside these areas, and increased flexibility in land policies call for the immediate introduction of these areas to some form of conservation to avoid irreparable damage to the world's largest rainforest. A fundamental question then is how to solve land property consolidation in the Amazon areas, which requires specific and simultaneous public policy actions.

In Europe and often worldwide, national and local government authorities employ different means to stimulate economic development and environmental protection of the land through the application of land consolidation [20]. This is even more necessary for Brazil, as the Brazilian Amazon has different levels of agricultural modernization. Lobão and Staduto [21] found that there is a heterogeneous and dual pattern of agricultural modernization in the Brazilian Amazon between municipalities in the west and north in the western Amazon region, which show the worst indicators of agricultural modernization, and those to the south and east (Eastern Amazon), with the best.

A second agricultural frontier area in Brazil is the Brazilian Northeast Region, which includes water restriction areas in tropical drylands. However, to achieve groundwater, food, and long-term energy security, agricultural landscapes in tropical drylands require more conservation (including the restoration of degraded areas), more diversification of agriculture practices, and better integration of individual initiatives at a larger spatial scale [10]. Tropical drylands are particularly sensitive to climate change. Carlos et al. [22] analyzed the relationship between farmers' knowledge about climate change and the adoption of adaptive strategies in the Bahia state and found that farmers who are aware of climate change effects are more likely to adapt.

In the Brazilian context, logistic requirements may also affect the expansion 
profile of agricultural areas. For example, soybean expansion in the Mato Grosso state is strongly associated with the presence of other soybean fields and warehouses within $50-100 \mathrm{~km}$, and soybean expansion is also likely to occur in areas of high conservation value [23]. Therefore, smart logistics investments are crucial for regional development and environmental protection.

Silva et al. [24] raised another issue. Their findings indicate that the total annual funding deficit in the Brazilian protected areas (PAs) increased in the last decade, including that for PAs in the Amazon, Atlantic Forest, Savannas, and drylands, requiring new policies, public-private partnerships, and innovative funding mechanisms to close the large funding gap in the Brazilian federal PA system.

Although some analysts highlight the negative environmental impacts of this process [25], especially those related to soybean and cattle breeding expansion, which leads to deforestation, other analysts [26] argue that agricultural expansion can serve both conservationists' and agricultural producers' interests.

Finally, several studies have evaluated the role of the Brazilian Forest Code (BFC). According to Hissa et al. [27], there are high expectations that the enforcement of the BFC will drive large-scale forest recovery and carbon mitigation. For the authors, trading certificates issued from recovering forests may represent a low-cost strategy for compliance with the BFC, a pathway for achieving restoration targets, and an additional source of income for landholders. In counterpart, Mueller [28] argued that the BFC key issue is the level of uncertainty of the gap between the de jure and de facto specification of property rights.

\section{Methodology and Data Source}

This study employs data from the Brazilian Institute of Geography and Statistics [29] comprising agricultural seeded areas ${ }^{1}$ at the Brazilian mesoregion level for 1995-2019, related exclusively to temporary crops. These include pineapple, cotton, garlic, peanut, rice, oat, potato, sweet potato, sugar cane, onion, rye, barley, pea, bean, tobacco, sunflower (2005 to 2019), jute, flax (seed), mallow, castor bean, manioc, watermelon, melon, corn, ramie, soybeans, sorghum, tomato, wheat, and triticale (2005 to 2019).

The methodology consists of four steps. First, a threshold for selecting mesoregions is established. Second, the study calculates the Spearman correlation coefficient for detecting those mesoregions where there is a time trend in the seeded area over 1995-2019. Third, a time trend was estimated for these mesoregions. Finally, cluster analysis is used to identify groups of mesoregions based on the estimated trends over time and similar mesoregions based on their pace of agricultural expansion during the period 1995-2019.

Each methodological step is described in detail in the following subsections.

${ }^{1}$ Henceforth, "agricultural area" always means agricultural seeded area, that is, an agricultural area for temporary crops. 


\subsection{Selecting Brazilian Mesoregions}

Brazil has 137 mesoregions, according to the IBGE [29]. Only mesoregions with superior expansion in agricultural areas were evaluated. To select these, the study established a lower bound, defined as the geometric growth rate (GGR) of the Brazilian agricultural area from 1995 to 2019. The geometrical growth rate is defined as follows:

$$
\mathrm{GGR}_{\mathrm{Br}}=25 \sqrt{\frac{\text { Seeded area }_{2019}}{\text { Seeded area }_{1995}}}-1
$$

Thus, only mesoregions with GGR above the Brazilian (national) level between the 25 years available, compose the group measured in Subsection 3.2.

\subsection{Spearman Correlation Coefficient}

Defining $\mathrm{Sh}_{i}$ as the share of mesoregion ${ }_{i}$ in the Brazilian agricultural area, the Spearman coefficient was used to evaluate whether the trend trajectory of $\mathrm{Sh}_{i}$ existed during the period 1995-2019. The respective test is non-parametric and does not require the original data to be normally distributed [30] [31]. Here, it means to calculate the correlation coefficient between the ranks of the $\mathrm{Sh}_{i}$ levels (S) and the time frame. The Spearman coefficient is represented by Equations (2) and (3).

$$
\rho=1-\frac{6 d}{N\left(N^{2}-1\right)}
$$

where:

$$
d=\sum_{1}^{T}\left[R_{t}-t\right]^{2}
$$

$R_{t}$ is the variable rank for the respective time moment, and $t=1,2,3, \cdots, T$ is the natural rank for the different time moments. The underlying idea is that the greater the difference between $R_{t}$ and $t$, the greater the probability of rejecting the null time trend.

\subsection{Time Trend Analysis}

If the Spearman coefficient test identifies a non-null time trend, a time trend will be estimated. As a first framework, the linear ${ }^{2}$ approach is employed, that is, the time $(T)$ is the explanatory variable for $\mathrm{Sh}_{i}$ according to Equation (4), where compound $u_{i}$ is assumed to respect the classical hypothesis of the residual in linear regression models.

$$
S h_{i}=\beta_{0}+\beta_{1} \cdot T+u_{i}
$$

The model decomposes the total sum of squares (TSS) into the explained sum of squares (ESS) and the residual sum of squares (RSS) [32], which is represented by Equation (5), where $S h_{i m}$ is the average share of each mesoregion in the Bra-

${ }^{2}$ Based on a more extensive series, more complex approaches could be applied. For example, including seasonal terms and a non-linear framework. 
zilian agricultural area over 1995-2019 for temporary crops; $S h_{i e}$ is the estimated value for each data; and $e_{e}$ is the corresponding residual.

$$
\mathrm{TSS}=\mathrm{ESS}+\mathrm{RSS}=\sum_{t=1}^{T}\left(S h_{i}-S h_{i m}\right)^{2}=\sum_{t=1}^{T}\left(S h_{i e}-S h_{i m}\right)^{2}+\sum_{t=1}^{T}\left(e_{e}\right)^{2}
$$

With the variance sources and degrees of freedom in each equation term, it is possible to apply ANOVA (Table 1 ), whose $F$-test allows evaluation of the statistical significance of the coefficients of (4).

\subsection{Clustering Mesoregions in Brazilian Agricultural Frontier Land}

The last methodological stage is the cluster analysis. The procedure is based on the mesoregions with a time trend detected according to the Spearman coefficient and estimated time trends. Cluster analysis has been employed to search for similarities among different individuals in a dataset for more than a century. Its use includes distinct research areas, such as Archaeology [33], Psychology, and Psychiatry [34] [35], and even related to taxonomic characteristics [36].

Agglomerative schedules can be divided into hierarchical and non-hierarchical agglomerative methods. The first corresponds to a step-by-step procedure to generate the clusters, while the second employs algorithms to maximize the homogeneity inside the groups without applying a hierarchical process for doing so.

Among the hierarchical agglomerative methods, the most commonly employed are the nearest (or single) neighbor linkage method, the further (or complete) neighbor linkage method, and the between (or average) group linkage method. These methods do not require a predefined number of clusters to function as agglomerative centers. Among the non-hierarchical agglomerative methods, the most employed is the k-means procedure, where agglomeration centers are defined that serve as the bases for locating individuals according to their proximity to such centers.

Here, except when referred, the procedures follow Johnson and Wichern [37] and employ the hierarchical agglomerative method for searching the number of clusters. This number of clusters, in turn, is the input for the non-hierarchical agglomerative k-means method.

To do so, cluster analysis employs the Euclidean distance, with a focus on the single (or nearest) distance. Accordingly, this approach is appropriate when the observations present high variability in the measured variables [38], which holds

Table 1. Analysis of variance (ANOVA).

\begin{tabular}{cccc}
\hline Source (A) & Degrees of freedom (B) & Mean square $=(\mathrm{A}) /(\mathrm{B})$ & $F$-test \\
\hline ESS & 1 & $\mathrm{ESS} / 1=\mathrm{MSE}$ & $F=\mathrm{MSE} / \mathrm{MSR}$ \\
$\mathrm{RSS}$ & $(n-2)$ & $\mathrm{RSS} /(n-2)=\mathrm{MSR}$ & \\
TSS & $(n-1)$ & $\mathrm{TSS} /(n-1)$ & \\
\hline
\end{tabular}

Source: Author, based on Barreto and Howland [32]. 
in this case because the range and variability of variables grow among the mesoregions during the period 1995-2019.

Euclidean distance is defined as a function of the $X$ variables associated with two sample elements and can be expressed as Equation (6), where the term $i$ is a variable or characteristic of each sample element and $k$ is the number of elements.

$$
d\left(X_{1}, X_{k}\right)=\left[\left(X_{1}-X_{k}\right)^{\prime}\left(X_{1}-X_{k}\right)\right]^{1 / 2}=\left[\sum_{i=1}^{p}\left(X_{i 1}-X_{i k}\right)^{2}\right]^{1 / 2}
$$

The calculations consisted of two steps. Initially, the agglomerative hierarchical method is employed, which indicates the number of groups that best fits the data. In the second round, the number of groups indicated is used for a K-means agglomerative non-hierarchical method. Once the agglomerative hierarchical and K-means agglomerative non-hierarchical methods have been run, their results can be compared.

In addition, it is possible to test the presence of different means among the clustered groups through another F-test approach [32] [39], according to the following hypothesis:

H0: variable (time trend) has the same average for every cluster;

Ha: variable (time trend) has a different average for at least one cluster.

It allows performing a cluster check for the hierarchical agglomerative, as well as for the k-means non-agglomerative procedures.

\section{Results and Discussion}

The GGR of the Brazilian agricultural area from 1995 to 2019 was $2.0 \%$. Of the 137 Brazilian mesoregions, only 41 had GGR values above or equal this value. Table 2 presents them in the GGR decreasing order, and the next methodological steps will be conducted exclusively with them.

For the temporary crops analyzed here, the 41 selected mesoregions had 32.6\% of the Brazilian agricultural seeded area in 1995 and 62.7\% in 2019; that is, they experienced a growth of 30 p.p. in the Brazilian seeded area over 25 years.

These mesoregions were concentrated in three Brazilian regions: 14 mesoregions in the Center-West, 10 in the Southeast, and 10 in the North. The regions in the South and Northeast contain four and three selected mesoregions, respectively. At the federation unit level, these mesoregions are concentrated in six federation units: seven in São Paulo (SP), five in Mato Grosso (MT), four in Mato Grosso do Sul (MS) and Goiás (GO), three in Rio Grande do Suo (RS), and three in Minas Gerais (MG).

\subsection{Spearman Correlation Coefficient test}

Once a mesoregion-targeted group was selected, the next step was the Spearman coefficient analysis. Table 3 presents the test results for the Brazilian agricultural mesoregions for temporary crops for the period 1995-2019. 
Table 2. Brazilian mesoregions selected according to the geometric growth rate (GGR).

\begin{tabular}{|c|c|}
\hline Mesoregion (Federation Unity) & GGR \\
\hline Amapá's North (AP) & $11.0 \%$ \\
\hline Tocantins Eastern (TO) & $9.5 \%$ \\
\hline Mato-grossense Northeast (MT) & $8.4 \%$ \\
\hline Mato-grossense North (MT) & $7.5 \%$ \\
\hline Maranhense South (MA) & $7.2 \%$ \\
\hline Amapá's South (AP) & $7.1 \%$ \\
\hline Piauiense Southwest (PI) & $5.9 \%$ \\
\hline Marajó (PA) & $5.8 \%$ \\
\hline Mato Grosso do Sul Southwest (MS) & $5.1 \%$ \\
\hline Goiano Northwest (GO) & $5.1 \%$ \\
\hline Tocantins Western (TO) & $5.1 \%$ \\
\hline Mato-grossense Center-South (MT) & $4.8 \%$ \\
\hline Goiano East (GO) & $4.8 \%$ \\
\hline Extreme West Bahia (BA) & $4.7 \%$ \\
\hline Mato Grosso do Sul Center-North (MS) & $4.7 \%$ \\
\hline Roraima's North (RR) & $4.4 \%$ \\
\hline Araçatuba (SP) & $4.3 \%$ \\
\hline Presidente Prudente (SP) & $4.2 \%$ \\
\hline Goiano North (GO) & $4.1 \%$ \\
\hline Paranaense Norhwest (PR) & $4.1 \%$ \\
\hline Goiano South (GO) & $3.9 \%$ \\
\hline Madeira-Guaporé (RO) & $3.9 \%$ \\
\hline São José do Rio Preto (SP) & $3.8 \%$ \\
\hline Marília (SP) & $3.8 \%$ \\
\hline Mato-grossense Southwest (MT) & $3.6 \%$ \\
\hline Rio-grandense Center-Western (RS) & $3.4 \%$ \\
\hline Triângulo Mineiro/Paranaíba Upstream (MG) & $3.3 \%$ \\
\hline Mato-grossense Southeast (MT) & $3.3 \%$ \\
\hline Itapetininga (SP) & $3.2 \%$ \\
\hline Federal District (DF) & $3.1 \%$ \\
\hline Rio-grandense Southwest (RS) & $3.0 \%$ \\
\hline Minas Northwest (MG) & $2.7 \%$ \\
\hline Rio-grandense Northeast (RS) & $2.6 \%$ \\
\hline Mato Grosso do Sul East (MS) & $2.6 \%$ \\
\hline
\end{tabular}




\begin{tabular}{cc}
\hline Bauru (SP) & $2.6 \%$ \\
Amazonense South (AM) & $2.5 \%$ \\
Campo das Vertentes (MG) & $2.5 \%$ \\
Paraense Southeast (PA) & $2.4 \%$ \\
Amazonense Center (AM) & $2.1 \%$ \\
South Mato-grossense Wetlands (MS) & $2.0 \%$ \\
Araraquara (SP) & $2.0 \%$ \\
Brazil & $2.0 \%$ \\
\hline
\end{tabular}

Source: Author, based on IBGE [29].

Table 3. Spearman coefficient tests for Brazilian agricultural mesoregions.

\begin{tabular}{|c|c|}
\hline Mesoregion (Federation Code) & Spearman Coefficient Test \\
\hline Amapá's North (AP) & $0.752^{* * *}$ \\
\hline Tocantins Eastern (TO) & $0.971^{* * *}$ \\
\hline Mato-grossense Northeast (MT) & $0.985^{* * *}$ \\
\hline Mato-grossense North (MT) & $0.992^{\star * *}$ \\
\hline Maranhense South (MA) & $0.984^{* * *}$ \\
\hline Amapás South (AP) & $0.962^{* * *}$ \\
\hline Piauiense Southwest (PI) & $0.981^{\star * *}$ \\
\hline Marajó (PA) & 0.305 \\
\hline Mato Grosso do Sul Southwest (MS) & $0.989^{* * *}$ \\
\hline Goiano Northwest (GO) & $0.722^{\star * \star}$ \\
\hline Tocantins Western (TO) & $0.824^{* * *}$ \\
\hline Mato-grossense Center-South (MT) & $0.858^{\star * *}$ \\
\hline Goiano East (GO) & $0.942^{* * *}$ \\
\hline Extreme West Bahia (BA) & $0.979^{\star * \star}$ \\
\hline Mato Grosso do Sul Center-North (MS) & $0.962^{\star \star \star}$ \\
\hline Roraima's North (RR) & 0.218 \\
\hline Araçatuba (SP) & $0.818^{\star * \star}$ \\
\hline Presidente Prudente (SP) & $0.857^{\star * \star}$ \\
\hline Goiano North (GO) & $0.913^{* * *}$ \\
\hline Paranaense Northwest (PR) & $0.827^{\star \star *}$ \\
\hline Goiano South (GO) & $0.913^{* * *}$ \\
\hline Madeira-Guaporé (RO) & 0.299 \\
\hline São José do Rio Preto (SP) & $0.796^{* * *}$ \\
\hline
\end{tabular}




\section{Continued}

\begin{tabular}{|c|c|}
\hline Marília (SP) & $0.776^{* * *}$ \\
\hline Mato-grossense Southwest (MT) & $0.848^{\star * \star}$ \\
\hline Rio-grandense Center-Western (RS) & $0.701^{* * *}$ \\
\hline Triângulo Mineiro/Paranaíba Upstream (MG) & $0.974^{* * *}$ \\
\hline Mato-grossense Southeast (MT) & $0.818^{\star * *}$ \\
\hline Itapetininga (SP) & $0.853^{* * *}$ \\
\hline Federal District (DF) & $0.842^{\star * *}$ \\
\hline Rio-grandense Southwest (RS) & $0.73^{\star * *}$ \\
\hline Minas Northwest (MG) & $0.898^{* * *}$ \\
\hline Rio-grandense Northeast (RS) & 0.113 \\
\hline Mato Grosso do Sul East (MS) & 0.073 \\
\hline Bauru (SP) & 0.357 \\
\hline Amazonense South (AM) & $-0.602^{* * *}$ \\
\hline Campo das Vertentes (MG) & -0.190 \\
\hline Paraense Southeast (PA) & -0.440 \\
\hline Amazonense Center (AM) & $-0.586^{\star * *}$ \\
\hline South Mato-grossense Wetlands (MS) & 0.130 \\
\hline Araraquara (SP) & 0.037 \\
\hline
\end{tabular}

Source: Author, based on IBGE [29]. Note: ${ }^{\star \star *} 1 \%$ significance level.

The Spearman coefficient test indicated that 31 mesoregions had a time trend for their share in the Brazilian agricultural area for temporary crops from 1995 to 2019. These mesoregions are concentrated in three Brazilian regions: 12 in the Center-West, 7 in the Southeast, and 6 in the North. ${ }^{3}$

At the federation unit level, Mato Grosso (MT) (five mesoregions), São Paulo (SP) (five mesoregions), and Goiás (GO) (four mesoregions) must be highlighted. These states belong to the states where spatial clusters of the most important states for Brazilian agriculture occur, as stated by Stege and Bacha [40].

Of the 41 evaluated mesoregions in this stage, 10 had no significant time trend, and they were not included in the further methodological stages.

\subsection{Time Trend}

The time trend was calculated for 31 Brazilian mesoregions, according to the results of the previous subsection. It measures the time trend of each mesoregion share in the Brazilian agricultural area for temporary crops over 1995-2019. Table 4 presents the corresponding results in descending order.

${ }^{3}$ In terms of Brazil's great regions, there is a funding deficit in protected areas in drylands, savanna, and the Atlantic Forest and Amazon protected areas in Brazil, but it is greater in the Amazon protected areas, that is, in the North [24]. 
Table 4. Time trends of mesoregion shares of Brazilian agricultural seeded area.

\begin{tabular}{|c|c|}
\hline Mesoregion (federation code) & Time trend \\
\hline Mato-grossense North (MT) & $0.004377^{* * *}$ \\
\hline Mato-grossense Northeast (MT) & $0.001254^{\star * \star}$ \\
\hline Mato Grosso do Sul Southwest (MS) & $0.001197^{\star * *}$ \\
\hline Goiano South (GO) & $0.00088^{\star * *}$ \\
\hline Extreme West Bahia (BA) & $0.000621^{* * *}$ \\
\hline Piauiense Southwest (PI) & $0.000471^{\star \star *}$ \\
\hline Maranhense South (MA) & $0.000425^{\star * \star}$ \\
\hline Triângulo Mineiro/Paranaíba Upstream (MG) & $0.000367^{\star * *}$ \\
\hline São José do Rio Preto (SP) & $0.000357^{\star \star *}$ \\
\hline Mato-grossense Southeast (MT) & $0.000337^{\star * *}$ \\
\hline Goiano East (GO) & $0.000335^{\star \star \star}$ \\
\hline Tocantins Eastern (TO) & $0.00032^{* * *}$ \\
\hline Presidente Prudente (SP) & $0.000239^{\star * *}$ \\
\hline Mato Grosso do Sul Center-North (MS) & $0.000236^{* * *}$ \\
\hline Tocantins Western (TO) & $0.00023^{* * *}$ \\
\hline Paranaense Northwest (PR) & $0.000199^{* * *}$ \\
\hline Minas Northwest (MG) & $0.000188^{\star * \star}$ \\
\hline Araçatuba (SP) & $0.00018^{\star * *}$ \\
\hline Rio-grandense Center-Western (RS) & $0.000161^{\star \star \star}$ \\
\hline Rio-grandense Southwest (RS) & $0.000129^{\star * *}$ \\
\hline Itapetininga (SP) & $0.000118^{\star * *}$ \\
\hline Mato-grossense Southwest (MT) & $0.000078^{\star * *}$ \\
\hline Goiano North (GO) & $0.000065^{\star \star \star}$ \\
\hline Mato-grossense Center-South (MT) & $0.00006^{* * *}$ \\
\hline Goiano Northwest (GO) & $0.000053^{\star * *}$ \\
\hline Marília (SP) & $0.000045^{\star * \star}$ \\
\hline Federal District (DF) & $0.000026^{\star * *}$ \\
\hline Amapá's South (AP) & $0.000012^{\star * *}$ \\
\hline Amapá's North (AP) & $0.000006^{\star * *}$ \\
\hline Amazonense South (AM) & $-0.000022^{* * *}$ \\
\hline Amazonense Center (AM) & $-0.000024^{\star * *}$ \\
\hline
\end{tabular}

Source: Author, based on IBGE [29]. Note: ${ }^{\star * \star} 1 \%$ significance level.

All 31 mesoregions presented time trends at the 1\% significance level for their share in the Brazilian agricultural seeded area for the period 1995-2019. Most of them have positive time trends, although Amazonense South (AM) and Amazo- 
nense Center (AM) show negative time trends. It must be noted that these two mesoregions are contiguous spaces in Brazilian territory.

In terms of time trend values, higher positive values are concentrated in the Center-West region; that is, in Mato-grossense North (MT), Mato-grossense Northeast (MT), and Mato Grosso do Sul Southwest (MS); while Goiano South (GO), Extreme West Bahia (BA), Piauiense Southwest (PI), and Maranhense South (MA) comprise the second group in this aspect. These seven mesoregions had an impact on Brazil's average trends.

In the Mato Grosso (MT) state, soybean expansion is strongly associated with the presence of other soybean fields and warehouses within $50-100 \mathrm{~km}$, and smart logistics investments are crucial for regional development with environmental protection [23].

Regarding the Bahia (BA), Piauí (PI), and Maranhão (MA) states, they belong to the Brazilian Northeast Region, which includes water restriction areas in tropical drylands. Further, to achieve groundwater, food, and long-term energy security, agricultural landscapes in tropical drylands require more conservation (including the restoration of degraded areas), more diversification of agriculture practices, and better integration of individual initiatives at a larger spatial scale [10].

Moreover, another group can be highlighted according to the results in Table 4. Triângulo Mineiro/Paranaíba Upstream (MG), São José do Rio Preto (SP), Mato-grossense Southeast (MT), Goiano East (GO), Tocantins Eastern (TO), Presidente Prudente (SP), Mato Grosso do Sul Center-North (MS), and Tocantins Western (TO) presented positive time trends in the [0.0002, 0.0004] interval. From the same perspective, Paranaense Northwest (PR), Minas Northwest (MG), Araçatuba (SP), Rio-grandense Center-Western (RS), Rio-grandense Southwest (RS), and Itapetininga (SP) embrace relatively lower positive time trends in the [0.0001, 0.0002] interval.

Although the estimated values are relatively small, they can exert a substantial long-term effect on the mesoregion share in the Brazilian agricultural seeded area. Knowing the expansion of the Brazilian area locations is quite important for adjusting and supporting the respective public policies in terms of infrastructure ${ }^{4}$, such as credit supply, technical assistance, and education for farmers.

Additionally, according to Pivoto et al. [16], the use of information and communication technology in farm management requires continuous education for farmers at all scales [16]. This process can produce a pack of productivity, profitability, and conservation of natural resources, but can also demand a higher production scale.

These results support the recent expansion of Brazilian agricultural frontier land in areas of the GO, MS, and MT states beyond the areas of MA, PI, and the BA states and the northern and eastern areas of the Tocantins state. The corresponding mesoregions expanded the limits of temporary crop areas in Brazil during the period 1995-2019.

${ }^{4}$ Cropper, Puri, and Griffiths [41] and Chomitz and Gray [42] have emphasized the role of roads in making access to markets easier. 


\subsection{Cluster Analysis of the Selected Mesoregions in the Brazilian Agricultural Area}

This section discusses some dispersion measures for the preparation of the clustering procedure to select the appropriate hierarchical agglomerative method. The greater the dispersion measures, the more appropriate is the single linkage method, which is appropriate when observations are distant from each other. The smaller the dispersion measures, the more appropriate is the complete linkage method, which is suitable when observations are near each other.

The data included only 31 mesoregions selected according to the previous methodological steps. Table 5 presents two dispersion measures. The first is the

Table 5. SD and $\mathrm{R}$ for selected mesoregions share in Brazilian agricultural area.

\begin{tabular}{|c|c|c|}
\hline Year & Standard Deviation (SD) & Range (R) \\
\hline 1995 & 0.010 & 0.04 \\
\hline 1996 & 0.010 & 0.04 \\
\hline 1997 & 0.011 & 0.05 \\
\hline 1998 & 0.013 & 0.05 \\
\hline 1999 & 0.014 & 0.06 \\
\hline 2000 & 0.014 & 0.06 \\
\hline 2001 & 0.015 & 0.07 \\
\hline 2002 & 0.016 & 0.07 \\
\hline 2003 & 0.017 & 0.08 \\
\hline 2004 & 0.018 & 0.09 \\
\hline 2005 & 0.020 & 0.10 \\
\hline 2006 & 0.019 & 0.09 \\
\hline 2007 & 0.019 & 0.09 \\
\hline 2008 & 0.020 & 0.10 \\
\hline 2009 & 0.019 & 0.10 \\
\hline 2010 & 0.020 & 0.10 \\
\hline 2011 & 0.021 & 0.10 \\
\hline 2012 & 0.023 & 0.12 \\
\hline 2013 & 0.024 & 0.13 \\
\hline 2014 & 0.024 & 0.12 \\
\hline 2015 & 0.025 & 0.13 \\
\hline 2016 & 0.025 & 0.13 \\
\hline 2017 & 0.026 & 0.14 \\
\hline 2018 & 0.026 & 0.14 \\
\hline 2019 & 0.027 & 0.15 \\
\hline
\end{tabular}

Source: Author, based on IBGE [29]. 


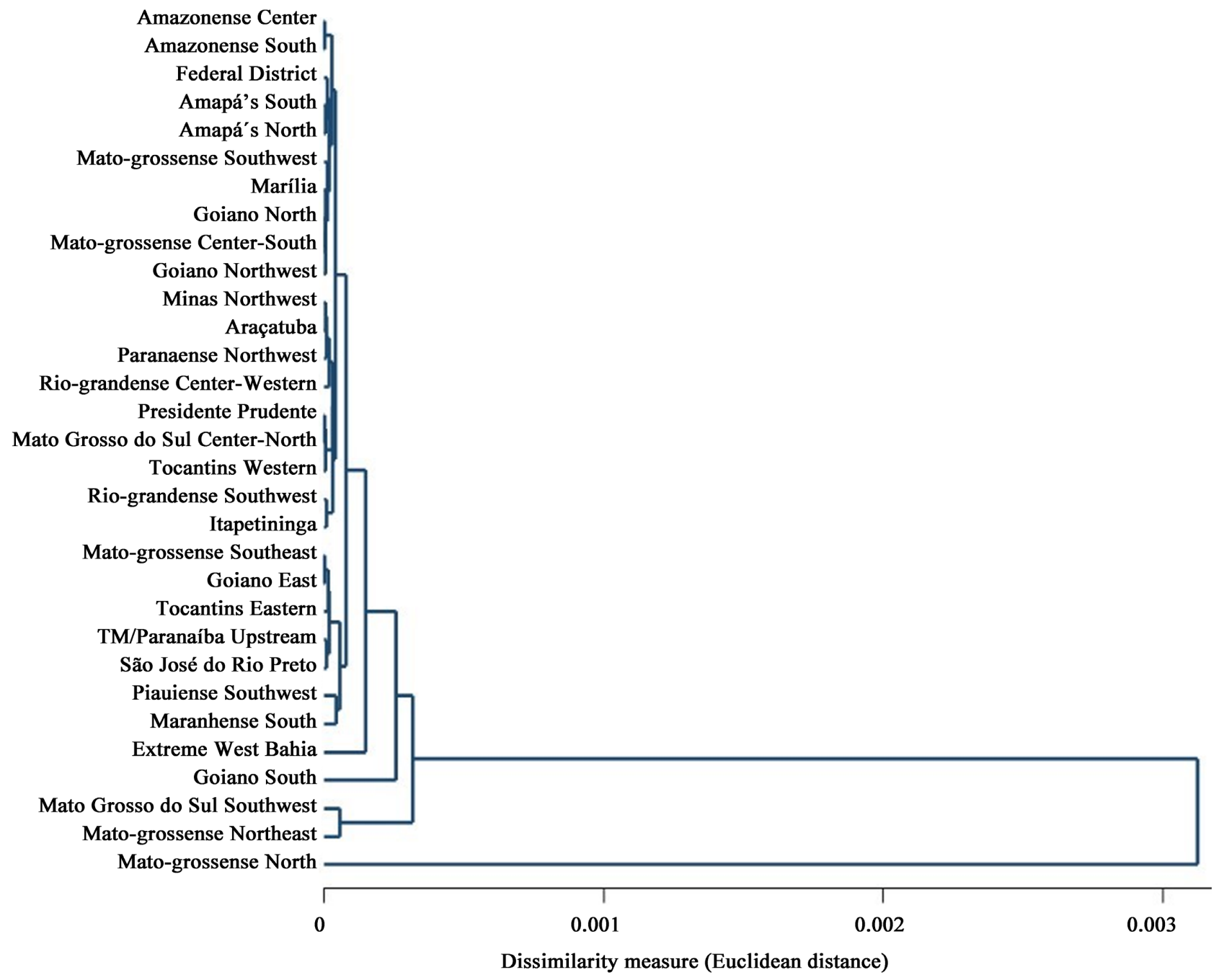

Figure 1. Dendrogram for the selected mesoregions.

${ }^{5}$ The Spearman coefficient correlation test for these series indicates a trend over time. When calculated in a linear version, both are significant at the $1 \%$ level. 
diagram representing a hierarchy of categories based on the degree of similarity or number of shared characteristics by a group of individuals in a set, commonly used in clustering analysis.

Figure 1 suggests that there are 12 subgroups of mesoregions based on similarities in their trends of area expansion during the period 1995-2019. These subgroups arise from jumps in the dissimilarity measures (Euclidean distance) presented on the $\mathrm{x}$-axis. The subgroups are:

- Amazonense Center and Amazonense South

- Federal District, Amapás South, and Amapá's North

- Mato-grossense Southwest, Marília, Goiano North, Mato-grossense Center-South, and Goiano Northwest

- Minas Northwest, Araçatuba, Paranaense Northwest, and Rio-grandense Center-Western

- Presidente Prudente, Mato Grosso do Sul Center-North, and Tocantins Western

- Rio-grandense Southwest and Itapetininga

- Mato-grossense Southeast, Goiano East, Tocantins Eastern, Paranaíba Upstream, and São José do Rio Preto

- Piauiense Southwest and Maranhense South

- Extreme West Bahia

- Goiano South

- Mato Grosso do Sul Southwest and Mato-grossense Northeast

- Mato-grossense North

Additionally, if $k=12$, the k-means non-hierarchical agglomerative method can also be used. Thus, it is possible to compare the results obtained using the two methods. Table 6 shows the results for the single linkage hierarchical agglomerative method (cluster) and the k-means non-hierarchical agglomerative method when $k=12$, as shown in Figure 1.

The results in Table 6 allow us to discuss at least four points. Firstly, by the hierarchical procedure, ten mesoregions belong to the same cluster (cluster 12), comprising a group of non-contiguous areas formed by mesoregions dispersed throughout the Brazilian territory. Conforming to the hierarchical procedure, seven mesoregions are clusters by themselves; that is, Mato-grossense North, Mato-grossense Northeast, Mato Grosso do Sul Southwest, Goiano South, Extreme West Bahia, Maranhense South, and Piauiense Southwest.

Most of these areas were located at the borders of the Amazon region. Regarding the environmental concerns, some strategies have been employed to achieve better results. As stated by Abman and Carney [15], there is some evidence that increasing the intensive margin of tenure (holding constant the extensive tenure) decreases deforestation. The authors studied the case of Vietnam and found that increases in crop production and land investment associated with holding land title are driven by the intensive margin, as well as obtaining some evidence that increasing the intensive margin of tenure (holding constant the 
Table 6. Mesoregions clusters according to the hierarchical and k-means non-hierarchical agglomerative methods.

\begin{tabular}{|c|c|c|c|}
\hline \multicolumn{2}{|l|}{ Hierarchical (cluster) } & \multicolumn{2}{|l|}{ K-means (non-hierarchical) } \\
\hline Mesoregion & Group & Mesoregion & Group \\
\hline Mato-grossense North & 1 & Amazonense South & 1 \\
\hline Mato-grossense Northeast & 2 & Amazonense Center & 1 \\
\hline Mato Grosso do Sul Southwest & 3 & Tocantins Eastern & 2 \\
\hline Goiano South & 4 & Mato-grossense Northeast & 3 \\
\hline Extreme West Bahia & 5 & Mato Grosso do Sul Southwest & 3 \\
\hline Maranhense South & 6 & Mato-grossense North & 4 \\
\hline Piauiense Southwest & 7 & Maranhense South & 5 \\
\hline Tocantins Eastern & 8 & Piauiense Southwest & 5 \\
\hline Goiano East & 8 & Amapá's North & 6 \\
\hline São José do Rio Preto & 8 & Amapá's South & 6 \\
\hline TM/Paranaíba Upstream & 8 & Federal District & 6 \\
\hline Mato-grossense Southeast & 8 & Extreme West Bahia & 7 \\
\hline Itapetininga & 9 & Goiano South & 8 \\
\hline Rio-grandense Southwest & 9 & Goiano Northwest & 9 \\
\hline Tocantins Western & 10 & Mato-grossense Center-South & 9 \\
\hline Mato Grosso do Sul Center-North & 10 & Goiano North & 9 \\
\hline Presidente Prudente & 10 & Marília & 9 \\
\hline Araçatuba & 11 & Mato-grossense Southwest & 9 \\
\hline Paranaense Northwest & 11 & Tocantins Western & 10 \\
\hline Rio-grandense Center-Western & 11 & Mato Grosso do Sul Center-North & 10 \\
\hline Minas Northwest & 11 & Araçatuba & 10 \\
\hline Amapá's North & 12 & Presidente Prudente & 10 \\
\hline Amapá's South & 12 & Paranaense Northwest & 10 \\
\hline Goiano Northwest & 12 & Minas Northwest & 10 \\
\hline Mato-grossense Center-South & 12 & Rio-grandense Center-Western & 11 \\
\hline Goiano North & 12 & Itapetininga & 11 \\
\hline Marília & 12 & Rio-grandense Southwest & 11 \\
\hline Mato-grossense Southwest & 12 & Goiano East & 12 \\
\hline Federal District & 12 & São José do Rio Preto & 12 \\
\hline Amazonense South & 12 & TM/Paranaíba Upstream & 12 \\
\hline Amazonense Center & 12 & Mato-grossense Southeast & 12 \\
\hline
\end{tabular}

Source: Author, based on IBGE [29]. 
extensive tenure) decreases deforestation.

Furthermore, institutional aspects are key to managing this process. In the United States, agricultural policy exerts substantial influence on cropland areas through the administration of the Conservation Reserve Program (CRP) [14]. Accordingly, the seriousness and precariousness of the protection of the Brazilian Amazon undesignated public forests (UPF), the rapid conversion of forests outside these areas, and increased flexibility in land policies call for the immediate identification of these areas for some form of conservation to avoid irreparable damage to the world's largest rainforest [19].

The fundamental question then is addressing land property consolidation in the Amazon areas, which can require specific and simultaneous public policy actions. In agreement with Stabile et al. [18], this includes providing quality technical assistance to small farmers that could help them better align production practices with local opportunities, increase household income and improve livelihoods, and reduce deforestation pressure. For these authors, in larger areas like the Amazon, for example, small farmers occupy a large swath and often lack access to technical assistance, production technology, and markets. In line with this argument, technologies like intercropping, smart farming, and livestock-farming-forest techniques are also useful for reducing forest impact and degradation.

Second, according to the k-means non-hierarchical procedure, the mesoregions were more evenly distributed than in the hierarchical procedure (cluster). However, four mesoregions are clusters by themselves: Tocantins Eastern, Mato-grossense North, Extreme West Bahia, and Goiano South. According to both procedures, these mesoregions seem to present specific dynamics in terms of Brazilian agricultural expansion for temporary crops.

Third, regardless of the clustering procedure, some mesoregions clustered together; for example, Goiano East, São José do Rio Preto, TM/Paranaíba Upstream, and Mato-grossense Southeast; Itapetininga, and Rio-grandense Southwest; Tocantins Western, Mato Grosso do Sul Center-North, and Presidente Prudente; Araçatuba, Paranaense Northwest, and Minas Northwest; Goiano Northwest, Mato-grossense Center-South, Goiano North, Marília, and Mato-grossense Southwest; and Amapá's North, Amapás South and Federal District. In many of these groups, geographically distant mesoregions had similar trends in agricultural area expansion for temporary crops from 1995 to 2019.

Finally, the k-means procedure seemed to be more suitable than the hierarchical procedure, as it identified more distributed mesoregions based on their trends of agricultural area expansion for temporary crops. Moreover, contiguous areas such as Amapás North and South and Amazonense Center and South belonged to the same clusters in both procedures.

The results presented in Table 6 were used to verify whether the clusters displayed different means for their trends in agricultural area expansion. Table 7 presents the corresponding results. Since the critical $F$-test value is 3.36 at the $1 \%$ 
Table 7. F-test results for the clustering procedures.

\begin{tabular}{cc}
\hline Procedure & F-test \\
\hline Hierarchical procedure (cluster) & $4213.6^{\star * \star}$ \\
Non-hierarchical procedure (k-means) & $3900.5^{\star * *}$ \\
\hline
\end{tabular}

Source: Author, based on IBGE [29]. Note: ${ }^{\star \star \star} 1 \%$ significance level.

Top mesoregions.

1. Mato-grossense North.

2. Mato-grossense Northeast.

3. Mato Grosso do Sul Southwest.

4. Goiano South.

5. Extreme West Bahia.

6. Maranhense South.

7. Piauiense Southwest.

8. Tocantins Eastern.

Second leading group.

9. Paranaíba Upstream.

10. São José do Rio Preto.

11. Mato Grossense Southeast.

12. Goiano East.

Northern highlighted areas.

13. Amapa's South.

14. Amapa's North.

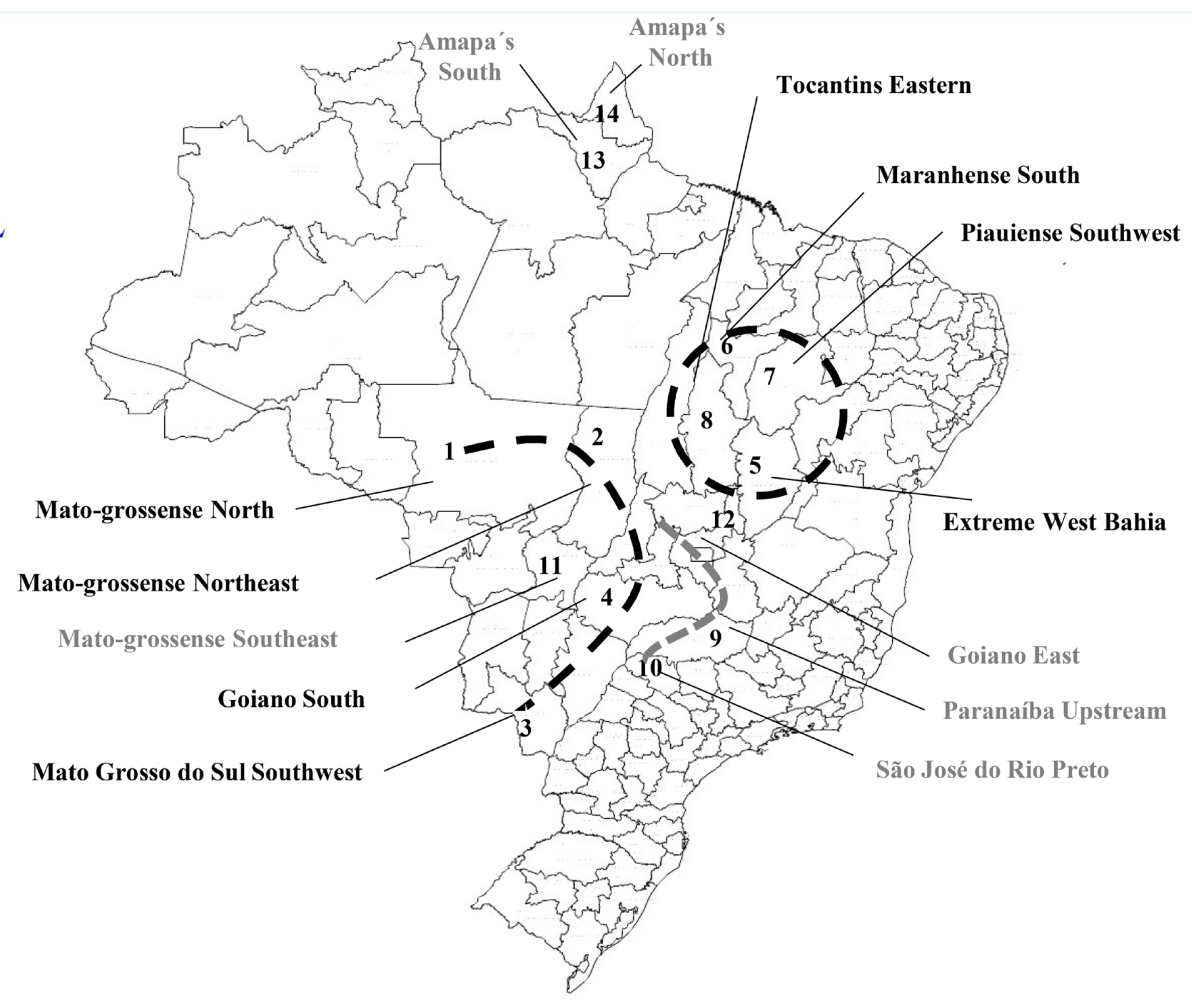

Source: Author, based on IBGE [29].

Figure 2. Highlighted areas in Brazilian agricultural area expansion (1995-2019).

significance level, they confirmed that the clusters displayed different means.

In summary, Figure 2 highlights the main results discussed thus far. It shows the main expanding mesoregions according to the measured crops and combines the results from Table 4 and Table 6 in terms of top mesoregions, a second leading group, and northern highlighted areas in Brazilian agricultural mesoregions.

\section{Concluding Remarks}

Knowing which areas comprise the Brazilian agricultural frontier is vital for improving the public policies and logistics infrastructure decisions. Equally, private actors linked to agricultural inputs can also employ such information to model their local operation strategies. Therefore, this study aimed to measure and map agricultural area expansion for temporary crops in Brazil from 1995 to 2019 at the mesoregion level.

The Center-West mesoregions showed higher positive trend values for their 
share in Brazilian agricultural areas, more specifically, in Mato-grossense North (MT), Mato-grossense Northeast (MT), Mato Grosso do Sul Southwest (MS), and Goiano South (GO). Concurrently, Extreme West Bahia (BA), Piauiense Southwest (PI), and Maranhense South (MA) composed a second group to be emphasized. All of them presented positive time trends in the interval [0.000425; 0.00438] and lead the Brazilian agricultural area expansion for temporary crops.

Most of these areas are on the borders of the Amazon region, and some strategies have been discussed to achieve better environmental results, such as increasing the intensive margin of tenure, institutional strengthening (identification of undesignated public forests to some form of conservation, and application of land consolidation) to overcome the powerless structure for controlling and monitoring frontier agricultural areas in Brazil, additionally, providing quality technical assistance for small farmers. Mutatis mutandis, these strategies are also welcome to frontier agricultural areas in MATOPIBA's savannas and drylands.

Other highlighted areas include Triângulo Mineiro/Paranaíba Upstream (MG), São José do Rio Preto (SP), Mato-grossense Southeast (MT), Goiano East (GO), Tocantins Eastern (TO), Presidente Prudente (SP), Mato Grosso do Sul Center-North (MS), and Tocantins Western (TO). They presented positive time trends in the $[0.000230 ; 0.000367]$ interval.

Notwithstanding, this group is near the southeastern regions and benefits from better logistic support conditions vis-à-vis the northern mesoregions and those from Maranhão, Tocantins, Piauí, and Bahia states. Regarding these states, the mesoregions featured here can benefit from railway expansion and consolidation; for example, the North-South and West-East integration railways.

The k-means non-hierarchical clustering method seemed to be more appropriate because its mesoregions were more evenly distributed than in the hierarchical procedure (cluster). Even so, according to both procedures, three mesoregions constitute clusters by themselves: Mato-grossense North (MT), Extreme West Bahia (BA), and Goiano South (GO). All of them presented a geometrical growth rate of $3.90 \%$ to $7.50 \%$ along the evaluated time, values substantially above the geometrical growth rate of $2.0 \%$ for all Brazilian mesoregions. Thus, they seem to present specific dynamics in terms of Brazilian agricultural expansion for temporary crops.

Regardless of the clustering procedure, several mesoregions clustered together. In many of these groups, geographically distant mesoregions had similar trends for their share in Brazilian agricultural area expansion for temporary crops from 1995 to 2019, which represents a puzzle and opens space for extensions of this study.

Moreover, further extensions can explore at least three other potential aspects. First, reproducing the study for permanent crops and comparing the results with those found here. Second, overlapping biome and infrastructure databases with the top mesoregions cited above. Finally, a top-down analysis targeting microre- 
gions or municipalities in the mesoregions that have already been identified.

\section{Acknowledgments}

We would like to thank Editage (www.editage.com/) for English language editing.

\section{Conflicts of Interest}

The author declares no conflicts of interest regarding the publication of this paper.

\section{References}

[1] United Nations (2019) World Population Prospects 2019. Online Edition, Revised. 1. https://population.un.org/wpp/Download/Standard/Population/

[2] Bruinsma, J. (2009) The Resource Outlook to 2050: By How Much Do Land, Water and Crop Yields Need to Increase by 2050? Expert Meeting on How to Feed the World in 2050, Food and Agriculture Organization of the United Nations Economic and Social Development Department, Rome.

[3] Iglesias, A., Quiroga, S. and Diz, A. (2011) Looking into the Future of Agriculture in a Changing Climate. European Review of Agricultural Economics, 38, 427-447. https://doi.org/10.1093/erae/jbr037

[4] Gasques, J.G., Botelho, F. and Bastos, E.T. (2015) Land Prices and Their Appreciation [Preço de terras e sua valorização]. Ministry of Agriculture, Livestock and Food Supply/Strategic Management Advisory [Ministério da Agricultura Pecuária e Abastecimento/Assessoria de Gestão Estratégica], Brasília.

[5] Câmara, G., Soterroni, A.C., Ramos, F.M., Carvalho, A.X.C., Mant, R., Andrade, P., Pena, M.G., Mosnier, A., Havlik, P., Pirker, J., Kraxner, F., Obersteiner, M. and Kapos, V. (2015) Modelling Land Use Change in Brazil: 2000-2050. INPE (National Institute for Space Research), IPEA (Institute of Applied Economic Research), IIASA (International Institute for Applied Systems Analysis), UNEPWCMC (World Conservation Monitoring Centre), São José dos Campos, Brasília, Laxenburg, Cambridge.

[6] Freitas, R.E. (2017) Expansion of Agricultural Area in Brazil: Soybeans versus Corn versus Cotton. Rural and Agro-Industrial Organizations [Organizações Rurais \& Agroindustriais], 19, 219-232. https://doi.org/10.21714/2238-68902017v19n3p219

[7] Awokuse, T.O. and Xie, R. (2015) Does Agriculture Really Matter for Economic Growth in Developing Countries? Canadian Journal of Agricultural Economics, 63, 77-99. https://doi.org/10.1111/cjag.12038

[8] Feltran-Barbieri, R. and Féres, J.G. (2021) Degraded Pastures in Brazil: Improving Livestock Production and Forest Restoration. Royal Society Open Science, 8, 1-15.

[9] Guilherme, J.D. and Vidica, B. (2019) Integration of Tree Crops and Pastures: Literature Review. African Journal of Agricultural Research, 14, 1091-1096. https://doi.org/10.5897/AJAR2018.13545

[10] Araújo, H.F.P., Machado, C.C.C., Pareyn, F.G.C., Nascimento, N.F.F., Araújo, L. D.A., Borges, L.A.A.P., Santos, B.A., Beirigo, R.M., Vasconcellos, A., Dias, B.O., Alvarado, F. and Silva, J.M.C. (2021) A Sustainable Agricultural Landscape Model for Tropical Drylands. Land Use Policy, 100, Article ID: 104913. https://doi.org/10.1016/j.landusepol.2020.104913

[11] Honga, Y., Heerink, N. and van der Werf, W. (2020) Farm Size and Smallholders' 
Use of Intercropping in Northwest China. Land Use Policy, 99, Article ID: 105004. https://doi.org/10.1016/j.landusepol.2020.105004

[12] Duveillera, G., Caporaso, L., Abad-Viñas, R., Perugini, K., Grassi, G., Arneth, A. and Cescatti, A. (2020) Local Biophysical Effects of Land Use and Land Cover Change: Towards an Assessment Tool for Policy Makers. Land Use Policy, 91, Article ID: 104382. https://doi.org/10.1016/j.landusepol.2019.104382

[13] Braito, M., Leonhardt, H., Penker, M., Schauppenlehner-Kloyber, E., Thaler, G., and Flint, C.G. (2020) The Plurality of Farmers' Views on Soil Management Calls for a Policy Mix. Land Use Policy, 99, Article ID: 104876. https://doi.org/10.1016/j.landusepol.2020.104876

[14] Hendricks, N.P. and Er, E. (2018) Changes in Cropland Area in the United States and the Role of CRP. Food Policy, 75, 15-23.

https://doi.org/10.1016/j.foodpol.2018.02.001

[15] Abman, R. and Carney, C. (2020) Land Rights, Agricultural Productivity, and Deforestation. Food Policy, 94, Article ID: 101841.

https://doi.org/10.1016/j.foodpol.2020.101841

[16] Pivoto, D., Barhamb, B., Waquil, P.D., Foguesatto, C.R., Corte, V.F.D., Zhang, D. and Talamini, E. (2019) Factors Influencing the Adoption of Smart Farming by Brazilian Grain Farmers. International Food and Agribusiness Management Review, 22, 571-588. https://doi.org/10.22434/IFAMR2018.0086

[17] Araújo, M.A., Martins, S.P., Sparovek, G, Ranieri, S.B.L. and Rocha Junior, A.B. (2020) Territorial Analysis, Development and Technical Assistance and Rural Extension for Family Farming. Brazilian Journal of Agriculture, 95, 123-139. https://doi.org/10.37856/bja.v95i2.4236

[18] Stabile, M.C.C., Guimarães, A.L., Silva, D.S., Ribeiro, V., Macedo, M. N., Coe, M. T., Pinto, E., Moutinho, P. And Alencar, A. (2020) Solving Brazil's Land Use Puzzle: INCREASING Production and Slowing Amazon Deforestation. Land Use Policy, 91, Article ID: 104362. https://doi.org/10.1016/j.landusepol.2019.104362

[19] Azevedo-Ramos, C., Moutinho, P, Arruda, V.L.S., Stabile, M.C.C., Alencar, A., Castro, I. and Ribeiro, J.P. (2020) Lawless Land in No Man's Land: The Undesignated Public Forests in the Brazilian Amazon. Land Use Policy, 99, Article ID: 104863. https://doi.org/10.1016/j.landusepol.2020.104863

[20] Pašakarnis, G., Maliene, V., Dixon-Gough, R. and Malys, N. (2021) Decision Support Framework to Rank and Prioritise the Potential Land Areas for Comprehensive Land Consolidation. Land Use Policy, 100, Article ID: 104908.

https://doi.org/10.1016/j.landusepol.2020.104908

[21] Lobão, M.S.P. and Staduto, J.A.R. (2020) Agricultural Modernization in the Brazilian Amazon. Brazilian Journal of Rural Economics and Sociology [Revista de Economia e Sociologia Rural], 58, Article ID: e188276.

https://doi.org/10.1590/1806-9479.2020.182276

[22] Carlos, S.M, Cunha, D.A. and Pires, M.V. (2019) Does Knowledge about Climate Change Imply Adaptation? Analysis of Farmers in Northeast Brazil. Brazilian Journal of Rural Economics and Sociology [Revista de Economia e Sociologia Rural], 57, 455-471. https://doi.org/10.1590/1806-9479.2019.187600

[23] Celidonio, O.L.M., Werner, L.S. and Gil, J.D.B. (2019) The Determinants of Recent Soybean Expansion in Mato Grosso, Brazil. International Food and Agribusiness Management Review, 22, 173-191. https://doi.org/10.22434/IFAMR2018.0072

[24] Silva, J.M.C., Dias, T.C.A.C., Cunha, A.C. and Cunha, H.F.A. (2021) Funding Defi- 
cits of Protected Areas in Brazil. Land Use Policy, 100, Article ID: 104926. https://doi.org/10.1016/j.landusepol.2020.104926

[25] Sauer, S. and Leite, S.P. (2012) Agricultural Expansion, Prices and Land Ownership by Foreigners in Brazil [Expansão agrícola, preços e apropriação de terra por estrangeiros no Brasil]. Brazilian Journal of Rural Economics and Sociology [Revista de Economia e Sociologia Rural], 50, 503-524. https://doi.org/10.1590/S0103-20032012000300007

[26] Sparovek, G., Antoniazzi, L.B., Barretto, A., Barros, A.C., Benevides, M., Berndes, G., Braga, E.P., Calmon, M., Groke Jr., P.H., Marques, F.N.A., Nogueira, M.P., Pinto, L.F.G. and Precioso, V. (2016) Sustainable Bioproducts in Brazil: Disputes and Agreements on a Common Ground Agenda for Agriculture and Nature Protection. Biofuels, Bioproducts and Biorefining, 10, 204-221. https://doi.org/10.1002/bbb.1636

[27] Hissa, L.B.V., Aguiar, A.P.D., Camargo, R.R., Lima, L.S., Gollnow, F. and Lakes, T. (2019) Regrowing Forests Contribution to Law Compliance and Carbon Storage in Private Properties of the Brazilian Amazon. Land Use Policy, 88, Article ID: 104163. https://doi.org/10.1016/j.landusepol.2019.104163

[28] Mueller, B. (2018) Property Rights Implications for the Brazilian Forest Code. Brazilian Journal of Rural Economics and Sociology [Revista de Economia e Sociologia Rural], 56, 329-346. https://doi.org/10.1590/1234-56781806-94790560209

[29] Brazilian Institute of Geography and Statistics [Instituto Brasileiro de Geografia e Estatística] (2021) Table 1612: Seeded Area, Harvested Area, Production, Average Yield and Production Value of Temporary Crops-Brazil and Mesoregions [Tabela 1612: Área plantada, área colhida, quantidade produzida, rendimento médio e valor da produção das lavouras temporárias-Brasil e Mesoregião Geográfica]. Brazilian Institute of Geography and Statistics. https://sidra.ibge.gov.br/tabela/1612

[30] Conover, W.J. (1999) Practical nonparametric statistics. 2nd Edition, Wiley, Hoboken.

[31] Morettin, P.A. and Toloi, C.M.C. (2006) Time Series Analysis [Análise de séries temporais]. 2nd Edition, Edgard Blücher, São Paulo.

[32] Barreto, H. and Howland, F.M. (2006) Introductory Econometrics: Using Monte Carlo Simulation with Microsoft Excel. Cambridge University Press, Cambridge.

[33] Driver, H.E. and Kroeber, A.L. (1932) Quantitative Expression of Cultural Relationships. University of California Publications in American Archeology and Ethnology, 31, 211-256.

[34] Zubin, J.A. (1938) Technique for Measuring Mindedness. Journal of Abnormal and Social Psychology, 33, 508-516. https://doi.org/10.1037/h0055441

[35] Zubin, J.A. (1938) Socio-Biological Types and Methods for Their Isolation. Psychiatry, 1, 237-247. https://doi.org/10.1080/00332747.1938.11022190

[36] Sokal, R.R. and Sneath, P.H.A. (1963) Principles of Numeric Taxonomy. W.H. Freeman and Company, New York.

[37] Johnson, R.A., and Wichern, D.W. (2007) Applied Multivariate Statistical Analysis. 6th Edition, Pearson Education, London.

[38] Fávero, L.P. and Belfiore, P. (2020) Data Analysis Handbook [Manual de análise de dados]. LTC, Rio de Janeiro.

[39] Greene, W.G. (2017) Econometric Analysis. Pearson, London.

[40] Stege, A.L. and Bacha, C.J.C. (2020) Spatial Clusters of "Agriculturalization" in the 
Rural Area of Some Brazilian States. Brazilian Journal of Rural Economics and Sociology [Revista de Economia e Sociologia Rural], 58, Article ID: e191298.

https://doi.org/10.1590/1806-9479.2020.191298

[41] Cropper, M., Puri, J. and Griffiths, C. (2001) Predicting the Location of Deforestation: The Role of Roads and Protected Areas in North Thailand. Land Economics, 77, 172-186. https://doi.org/10.2307/3147088

[42] Chomitz, K.M. and Gray, D.A. (1996) Roads, Land Use, and Deforestation: A Spatial Model Applied to Belize. The World Bank Economic Review, 10, 487-512.

https://doi.org/10.1093/wber/10.3.487 